\title{
MICROSCOPIC ANALYSIS OF DOG DENTAL PULPAFTER PULPOTOMY AND PULP PROTECTION WITH MINERAL TRIOXIDE AGGREGATE AND WHITE PORTLAND CEMENT
}

\author{
ANÁLISE MICROSCÓPICA DA POLPA DENTAL DE CÃES APÓS PULPOTOMIA E PROTEÇÃO \\ PULPAR COM AGREGADO DE TRIÓXIDO MINERAL E CIMENTO PORTLAND BRANCO
}

\begin{abstract}
Renato MENEZES ${ }^{1}$, Clóvis Monteiro BRAMANTE², Roberto Brandão GARCIA ${ }^{3}$, Ariadne LETRA ${ }^{4}$, Vanessa Graciela Gomes CARVALHO ${ }^{5}$, Everdan CARNEIRO $^{1}$, Sérgio BRUNINI ${ }^{6}$, Rodrigo Cardoso OLIVEIRA7 Giovana Calichio CANOVA ${ }^{1}$, Fernanda Gomes de MORAES ${ }^{1}$
\end{abstract}

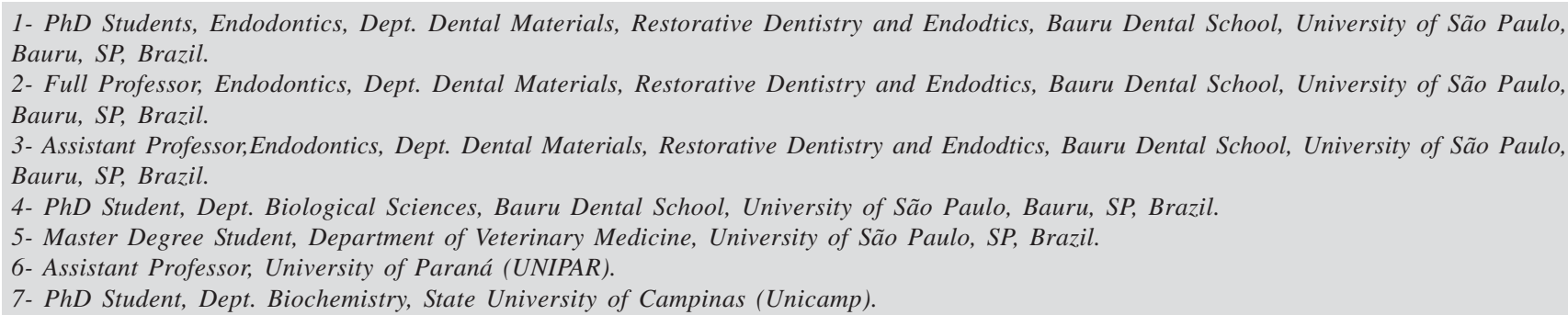

\begin{abstract}
Considering previous studies on the similarity between the chemical composition of the mineral trioxide aggregate and the Portland cement, the purpose of this study was to investigate the pulp response of dog's teeth after pulpotomy and direct pulp protection with MTAAngelus and white Portland cement. Thirty eight pulp remnants were protected with these materials. One hundred and twenty days after treatment, the animals were sacrificed and the specimens removed and prepared for histological analysis. Both materials demonstrated the same results when used as pulp capping materials, inducing hard tissue bridge formation and maintaining pulp vitality in all specimens. The MTA Angelus and the white Portland cement showed to be effective as pulp protection materials following pulpotomy.

UNITERMS: Pulpotomy; Mineral trioxide aggregate; White Portland cement.
\end{abstract}

\section{RESUMO}

C Considerando estudos anteriores sobre a similaridade entre a composição química do agregado de trióxido mineral e o cimento Portland, o objetivo deste estudo foi investigar a resposta pulpar de dentes de cães após pulpotomia e proteção pulpar direta com MTA Angelus e cimento Portland branco. Trinta e oito remanescentes pulpares foram recobertos com esses materiais. Cento e vinte dias após o tratamento, os animais foram sacrificados e os espécimes removidos e preparados para análise histológica. Ambos os materiais demonstraram os mesmos resultados quando utilizados como materiais de capeamento pulpar, induzindo a formação de ponte de tecido mineralizado e mantendo a vitalidade pulpar em todos os espécimes. Ambos matérias se mostraram efetivos como protetores pulpares após pulpotomia em dentes de cães.

UNITERMOS: Pulpotomia; MTA; Cimento Portland branco.

\section{INTRODUCTION}

Recent research in Endodtics has been focused on the ability of various techniques and materials to enhance optimal tissue healing.
Mineral trioxide aggregate (MTA) was developed as a root-end filling material for periapical surgery and for the sealing of communications between the root canal system and the surrounding tissues ${ }^{15}$.

MTA has been used in pulp capping procedures in 
animal $^{5,10,12}$ and human teeth, ${ }^{2}$ and demonstrated remarkable success compared to calcium hydroxide. Previous studies claim similar success rates also after pulpotomies ${ }^{7,14}$.

Wucherpfenning and Green ${ }^{17}$, reported that both MTA and Portland cement (PC) seem almost identical macroscopically, microscopically and by X-ray diffraction analysis. They reported that both substances support matrix formation in a similar manner in cultures of osteoblast-like cells, and also apposition of reparative dentin when used as a direct pulp capping material in rat teeth. Other authors ${ }^{3,6}$ reported that the Portland cements contain the same chemical elements as MTA, except that MTA also contains bismuth.

MTA, white MTA and PC formed calcite crystal granulations when placed in dentin tubes subcutaneously implanted in rats, suggesting that the mechanisms of action of these materials are very similar ${ }^{8,9}$.

Saidon, et al. ${ }^{13}$, demonstrated that MTA and PC have comparative biocompatibility when evaluated in vitro and in vivo, suggesting that PC has the potential to be used as a less expensive root-end filling material.

The purpose of this study was to investigate the properties of MTA Angelus, a Brazilian product, and white Portland cement used as pulp capping materials after pulpotomy in intact dog's teeth.

\section{MATERIAL AND METHODS}

Thirty-eight teeth of four mongrel dogs, 12-18 months of age, were used in this experiment. Under general anesthesia with Telazol (Fort Dodge, USA) and with a rubber dam in place, the pulp was mechanically exposed via class $\mathrm{V}$ cavities in the canines and incisors, and through occlusal cavities in pre-molars. Teeth with fractures or other problems like pulp exposure were discarded. The coronal portion of the pulp was removed with a bur and a spoon-shaped excavator. Light pressure with sterile cotton pellets and copious irrigation with sterile saline solution were applied to control hemorrhage. The pulp remnants were protected with MTA Angelus (Angelus Soluções odontológicas, Londrina, Brazil) and white Portland cement (Irajazinho, Votorantim-cimentos, SP, Brazil), with a total of 19 teeth per material. All animals received both materials tested, randomly divided between the teeth of each animal. Both materials were mixed into a paste consisting of 3:1 powder-sterile saline. White Portland cement was previously sterilized by gamma rays. The materials used in this investigation were placed at the exposure site and light pressure was applied with a wet cotton pellet to accommodate the materials. The cavities were sealed with Coltosol (Colthene-Whaledent, Ca, USA) and restored with amalgam (SS White, SP, Brazil). One hundred and twenty days after treatment, the animals were sacrificed and received injection of $10 \%$ buffered formalin; the respective mandible sections were removed and placed in $10 \%$ buffered formalin before demineralization in formic acid buffered with sodium citrate. Tissue blocks were then dehydrated and embedded in paraffin. Serial sections (6-ìm thick) were stained with hematoxylin and eosin. Sections were examined by two observers. They were assessed for the presence and quality of the hard tissue bridge (continuity, morphological aspects, and thickness), inflammatory reaction (chronic or acute, number of cells and extension of the reaction), hyperemia, presence of giant cells, particles of capping material and dentin.

\section{RESULTS}

Although statistical analysis was not performed in this study, similar results were observed for both materials. Satisfactorily thick mineralized bridges were formed, closing the access openings in all cases. In many cases, a nearly odontoblastic layer was noted. No inflammation, necrosis or calcifications were registered.

\section{MTA Angelus}

In all specimens, the access opening cavities were sealed by a basophilic-like mass representing the material. The coronary third of the canal was completely sealed by a newly formed tubular mineralized tissue of homogeneous aspect in most specimens, and slightly atubular in some specimens. Dentin bridges of large thicknesses were seen.

The pulp connective tissue presented characteristics of normality and a small segment of cells adhered to the mineralized mass. This mass grew into the canal walls (Figure 1 and 2). Inflammation, hyperemia, necrosis and calcifications were not observed.

\section{White Portland cement}

In this group, the dentin bridges formed were very thick, of homogeneous tubular aspect in most cases, completely sealing the pulp exposure (Figure 3 ). The pulp tissue was also normal.

All specimens presented formation of mineralized structure at the access opening extending into the canal. Normal pulp characteristics with odontoblasts adhered to the mineralized mass were always observed. Inflammation, hyperemia, necrosis and calcifications were not observed.

\section{DISCUSSION}

According to Holland, et al. ${ }^{8}$, it is possible that the mechanism of action of MTA, encouraging hard tissue deposition, shows some similarity to that of calcium hydroxide. Recently, studies have compared MTA with PC and the findings suggest that PC has major ingredients in common with MTA. Some of these ingredients are calcium phosphate, calcium oxide, and silica. MTA also contains bismuth oxide, which increases its radiopacity, and is absent in the $\mathrm{PC}^{3,6,17}$.

Several studies ${ }^{2,4,5,7,10,11,12,14,16,17}$ have reported excellent results when using MTA over pulp. However, only two studies reported the use of Portland cement in conservative 


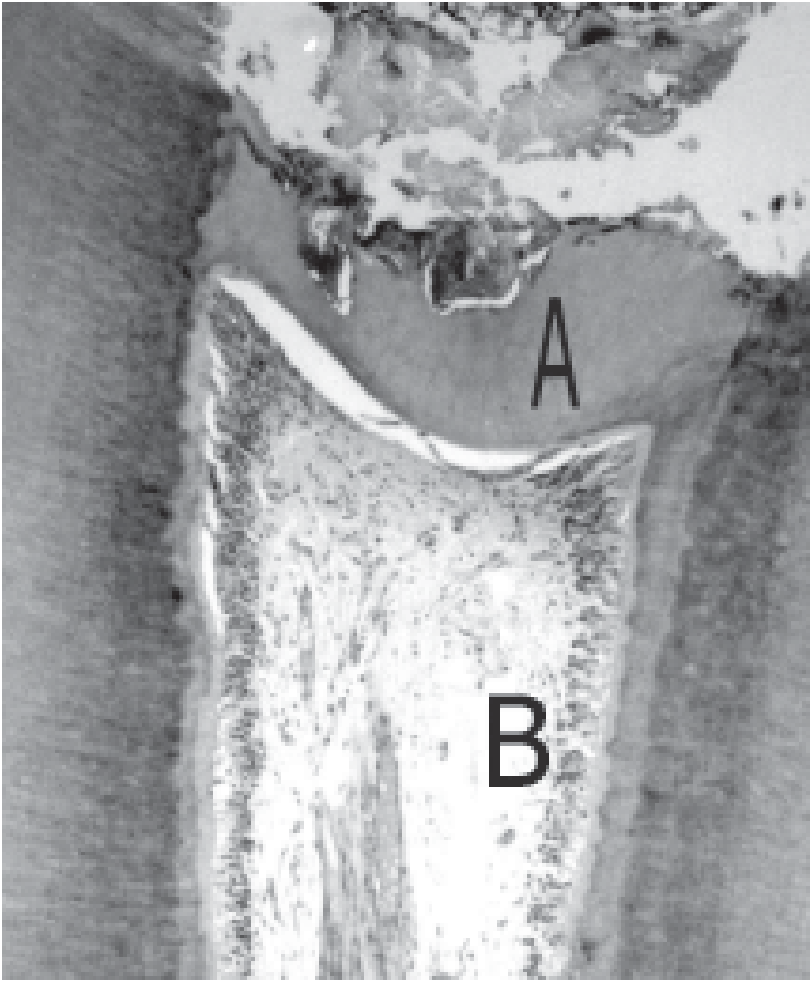

FIGURE 1- MTA Angelus (120 days), H.E. 25 X. Note the presence of a mineralized barrier $(A)$ sealing the pulp exposures. The connective pulp tissue presents characteristics of normality (B)

pulp therapy with considerable success in rats ${ }^{17}$ and dogs ${ }^{7}$, complying with the present results. Nevertheless, there is no previous record of any study referring to the use of white Portland cement over pulp, and only Faraco ${ }^{4}$ tested a white MTA over pulp and observed satisfactory results. Since a new white MTA has been recently introduced in the market, the present study was designed to test the white Portland cement as another option for conservative pulp therapy, and observed that this material was able to induce hard tissue formation and maintain the connective pulp tissue free of inflammation and necrosis after 120 days.

It should be emphasized that all teeth were free of caries and inflammation. It is know that the presence of bacteria is a significant inhibiting factor for healing of pulp exposures. The ability of MTA Angelus and white Portland cement to induce the formation of a dentin bridge may be due to its excellent sealing ability and fast setting time, around 5 minutes, avoiding diffusion of the material into the tissues, and microleakage throughout the entire procedure.

Other studies with various types of Portland cement should be conducted, like Abdullah, et al. ${ }^{1}$, who tested an accelerated Portland cement with a restorative material and demonstrated evidences that these materials are non-toxic and may have potential to promote bone healing.

The materials tested were capable of inducing hard tissue deposition over pulpotomized teeth, preserving pulp vitality and therefore showing to be effective pulp capping materials.

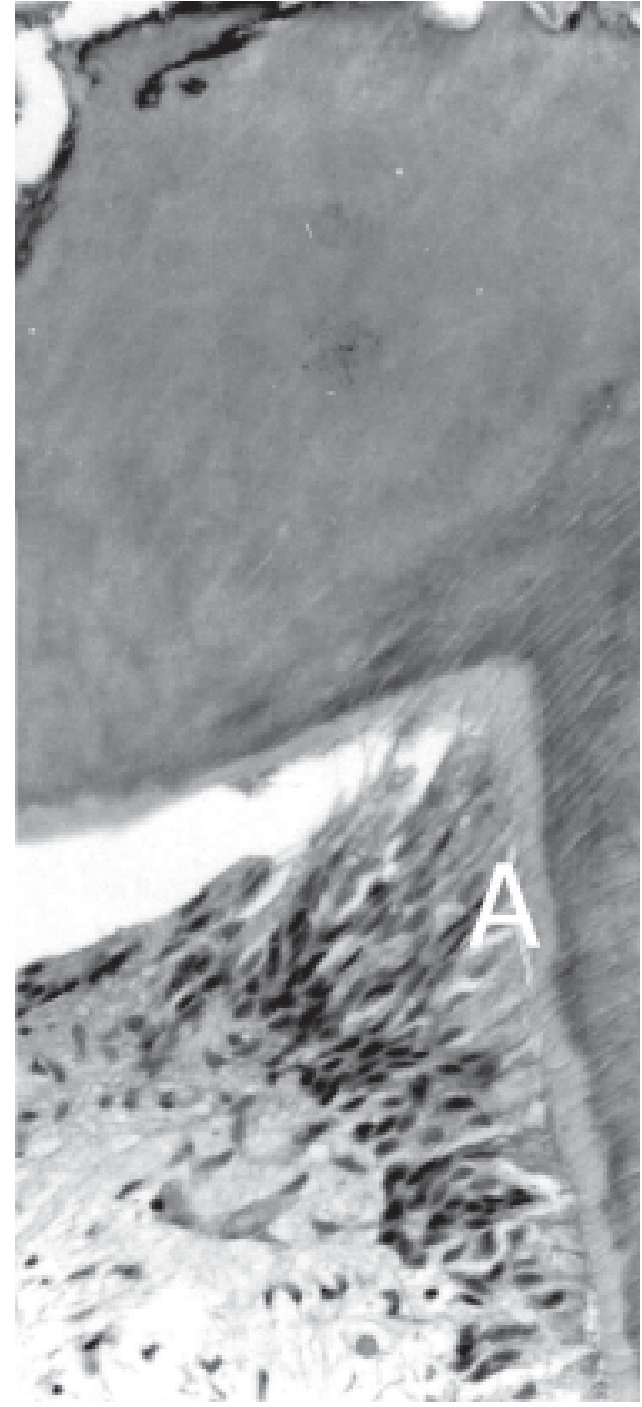

FIGURE 2- MTAAngelus (120 days). H.E. 40 X. Presence of odontoblasts (A)

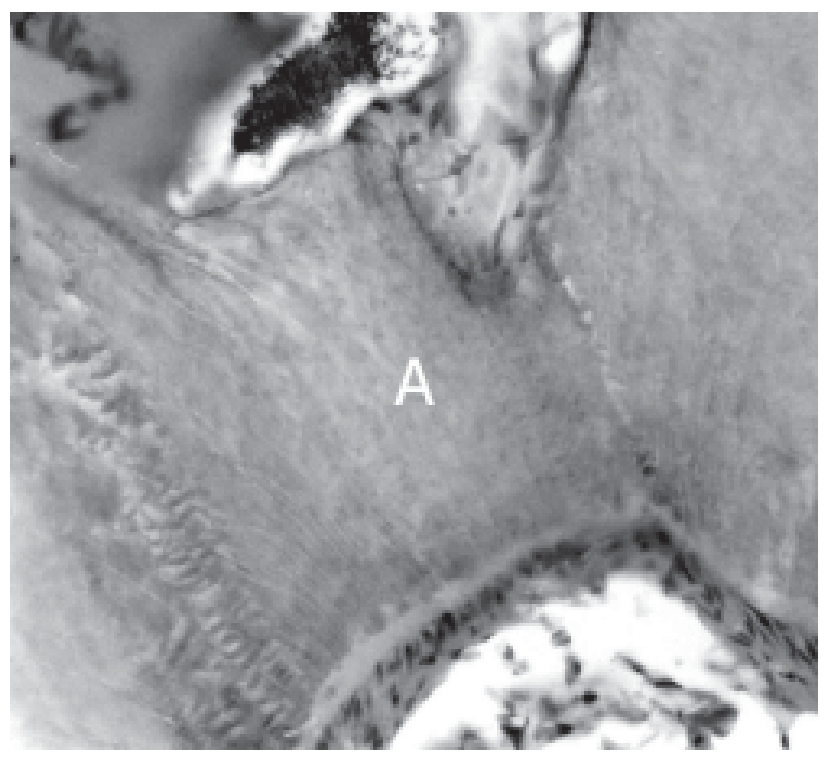

FIGURE 3- White Portland cement (120 days). H.E. 40 X. (A) Dentin bridge 
MTA is a common product in our daily routine. The results from this study and others support the idea that PC and white Portland cement have the potential to be used in clinical situations similar to those in which MTA is being used; however further studies involving Portland cement and white Portland cement are necessary to indicate their clinical use.

\section{REFERENCES}

1- Abdullah D, Ford TR, Papaioannou S, Nicholson J, McDonald F. An evaluation of accelerated Portland cement as a restorative material. Biomaterials 2002; 23: 4001-10.

2- Aeinehchi M, Eslami B, Ghanbariha M, Saffar AS. Mineral trioxide aggregate (MTA) and calcium hydroxide as pulp-capping agents in human teeth: a preliminary report. Int Endod J 2002; 36: 225-31.

3- Estrela C, Bammann LL, Estrela CRA, Silva RS, Pécora JD: Antimicrobial and chemical study of MTA, Portland cement, calcium hydroxide paste, sealapex and Dycal. Braz Dent J 2000; 11:19-27.

4- Faraco Júnior IM. Avaliação histomorfológica da resposta da polpa de dentes de cães submetida ao capeamento com sistema adesivo, cimento de hidróxido de cálcio e dois tipos de agregado de trióxido mineral. Araçatuba; 1999 [Thesis Doctor - Faculdade de Odontologia da UNESP]

5- Faraco Júnior IM, Holland R. Response of the pulp of dogs to capping with mineral trioxide aggregate or a calcium hydroxide cement. Dental Traumatol 2001;17:163-6.

6- Funteas UR, Wallace JA, Fochtman EW. A comparative analysis of Mineral Trioxide Aggregate and Portland cement. Aust Endod J 2003; 29: 43-4.

7- Holland R, Souza V, Murata SS, Nery MJ, Bernabé PFE, Otoboni Filho JA, Dezan Junior E. Healing process of dog dental pulp after pulpotomy and pulp covering with mineral trioxide aggregate or Portland cement. Braz Dent J 2001;12: 109-13.

8- Holland R, Souza V, Nery MJ, Otoboni Filho JA, Bernabe PFE, Dezan Junior E. Reaction of rat connective tissue to implanted dentin tubes filed with mineral trioxide aggregate or calcium hydroxide. J Endod 1999; 25:161-6.

9- Holland R, Souza V, Nery MJ, Faraco Júnior IM, Bernabé PFE, Otoboni Filho JA, Dezan Júnior E. Reaction of rat connective tissue to implanted dentin tubes filled with white trioxide aggregate mineral. Braz Dent J 2002; 13: 23-6.

10- Junn DJ, McMillan P, Bakland LK, Torabinejad M. Quantitative assessment of dentin bridge formation following pulp capping with mineral trioxide aggregate (MTA) [abstract]. J Endod 1998; 24:278.

11- Menezes R, Letra A, Bramante CM, Carvalho VGG. Microscopic analysis of the tissue response of dog's teeth after pulp capping with two types of mineral trioxide aggregate. J Dent Res 2003; 82(sp issue): B-322.
12- Pitt Ford TR, Torabinejad M, Abedi HR, Bakland LK, Kariyawasan SP. Using mineral trioxide aggregate as a pulp-capping material. J Am Dent Assoc 1996; 127:1491-6.

13- Saidon J, He J, Zhu Q, Safavi K, Spangberg LSW. Cell and tissue reactions to mineral trioxide aggregate and Portland cement. Oral Surg Oral Med Oral Pathol Oral Radiol Endod 2003; 95:4839.

14- Soares IML. Resposta pulpar ao MTA-agregado de trióxido mineral-comparado ao hidróxido de cálcio em pulpotomias. Histológico em dentes de cães. Florianópilis; 1996. [Thesis Faculdade de Odontologia, UFSC].

15- Torabinejad M, Watson TF, Pitt Ford TR. Sealing ability of a mineral trioxide aggregate when used as a root end filling material. J Endod 1993; 19:591-5.

16- Tziafas D, Pantelidou O, Alvanou A, Belibasakis G, Papadimitriou S. The dentinogenic effect of mineral trioxide aggregate (MTA) in short-term capping experiments. Int Endod J 2002;35: 245-54.

17- Wucherpfennig AL, Green DB. Mineral trioxide vs Portland cement: two biocompatible filling materials [abstract]. J Endod 1999; 25:308. 